\title{
Efficacy of Flavonoids for Patients with Japanese Cedar Pollinosis
}

\author{
Toshio Tanaka
}

Additional information is available at the end of the chapter

http://dx.doi.org/10.5772/45882

\section{Introduction}

The worldwide prevalence of allergic diseases such as asthma, atopic dermatitis and allergic rhinitis has increased during the last two decades (Holgate, 1999; Eder et al., 2006). Allergic rhinitis now affects 400-500 million people worldwide (Greiner et al., 2011; Ozdoganoglu \& Songu, 2012) and adversely affects social life, school performance, and work productivity (Bousquet et al., 2001). The first case of Japanese cedar pollinosis in Japan was reported in the mid-1960s (Horiguchi \& Saito, 1964), but now half of the Japanese population have become sensitized to Japanese cedar pollens and $24-29 \%$ of the population is suffering from the disease (Kaneko et al., 2005), so that Japanese cedar pollinosis is now rated as one of the most common diseases in Japan (Okamoto et al., 2009). The complicated interaction between genetic and environmental factors is thought to cause the development of allergic diseases. Many genetic loci related to atopy, a genetic tendency to produce immunoglobulin E (IgE) in response to environmental allergens, have been identified through genome-wide association studies (Grammatikos, 2008). However, changes in the environment have made a more significant contribution than genetic factors to the recent increase in the prevalence of allergic diseases (Nolte et al., 2001; Ho, 2010), since it seems unlikely that genes would have changed during the last two decades. Dietary change has been proposed as one of the environmental factors responsible for the increasing prevalence or the worsening symptoms of allergic diseases (Devereux \& Seaton, 2005; Devereux, 2006; Kozyrskyj et al., 2011; Nurmatov et al., 2011; Allan \& Devereux, 2011). Indeed foods include both allergypromoting and anti-allergic nutrients (McKeever \& Britton, 2004), and flavonoids, which are plant secondary metabolites, can have powerful antioxidant, anti-allergic and immunemodulating effects (Hollman \& Katan, 1999; Middleton et al., 2000; Manach et al., 2004). This review article introduces the anti-allergic properties and efficacy of flavonoids for patients with Japanese cedar pollinosis and discusses the possibility that an appropriate intake of 
flavonoids may constitute an effective complementary and alternative medicine as well as a preventative strategy for allergic diseases.

\section{Flavonoids possess anti-allergic activity}

In the mid-1990s we evaluated the clinical efficacy of one kind of traditional vegetarian diet on adult patients with severely to moderately active atopic dermatitis. After a two-month treatment period, the severity of dermatitis had decreased from 49.9 to 27.4 based on the SCORAD index, a score of atopic dermatitis severity, in association with a reduction in the number of peripheral blood eosinophils and the amount of urinary secretion of 8-hydroxy2'-deoxyguanosine, a marker of oxidative DNA damage (Kouda et al., 2000; Tanaka et al., 2001). What factor(s) led to this amelioration of dermatitis remained unknown but subsequently it was found that one of the characteristics of the remedy was a high daily intake of flavonoids.

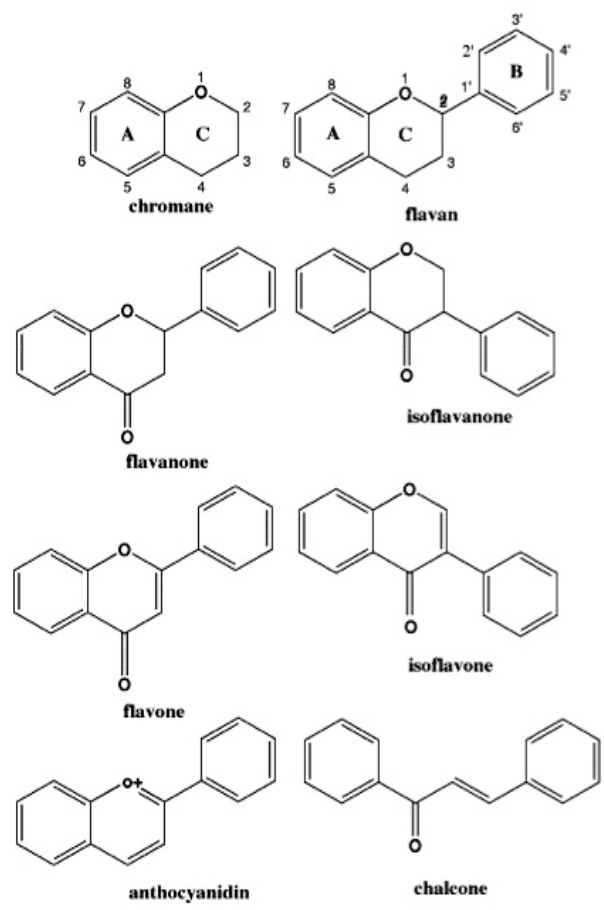

Figure 1. Structures of basic flavonoid skeletons

Flavonoids are comprised of a large group of low-molecular-weight polyphenolic secondary plant metabolites that are found in fruit, vegetables, cereals and beverages, and thus are common substances in the daily diet (Hollman \& Katan, 1999; Middleton et al., 2000). Based on their skeleton, flavonoids are classified into eight groups: flavans, flavanones, isoflavanones, flavones, isoflavones, anthocyanidins, chalcones and flavonolignans (Fig. 1). 
Flavonols constitute a separate class of flavonoids that possess the 3-hydroxyflavone backbone. Typical flavonoids such as quercetin, kaempferol, fisetin and myricetin belong to flavonols while luteolin and apigenin are classified as flavones. Flavonoids have been found to exert several biological activities including antioxidant, anti-bacterial and anti-viral activities, and to have anti-inflammatory, anti-angionic, analgestic, hepatoprotective, cytostatic, apoptotic, estrogenic or anti-estrogenic and immune-modulating effects as well as anti-allergic properties (Harborne \& Williams, 2000; Williams \& Grayer, 2004; Chirumbolo, 2010; Visioli et al., 2011; Calderon-Montano et al., 2011; Russo et al., 2012). As a result, considerable interest has been paid to the role of flavonoids in the prevention of chronic diseases, including cardiovascular diseases, cancers, type 2 diabetes, neurodegenerative diseases, osteoporosis and allergic diseases (Sealbert et al., 2005).

Mast cells and basophils expressing the high-affinity IgE receptor (FceRI) play an important role in allergic inflammation by releasing chemical mediators such as histamine and cyteinyl leukotrienes, cytokines and chemokines (Stone et al., 2010). As for the anti-allergic activities of flavonoids, Fewtress and Gomperts first identified the inhibition by flavones of transport ATPase in histamine secretion from rat mast cells (Fewtrell \& Gomperts, 1997). Fisetin, quercetin, myricetin and kaempferol were found to inhibit histamine release while morin and rutin showed little effect. Subsequently, quercetin was reported to inhibit histamine release by allergen-stimulated human basophils (Middleton et al., 1981; Middleton \& Kandaswami, 1992). Flavonoids such as apigenin, luteolin, 3,6-dihydroxy flavones, fisetin, kaempferol, quercetin, and myricetin, all with IC50 values of less than $10 \mu \mathrm{M}$, were found to inhibit hexosaminidase release from rat mast cells (Cheong et al., 1998). In addition, flavonoids have also been shown to suppress cysteinyl leukotriene synthesis through inhibition of phospholipase $\mathrm{A}_{2}$ and 5-lipoxygenase (Lee et al., 1982; Yoshimoto et al., 1983). As for the suppressive effect of flavonoids on cytokine expression, Kimata et al were the first to report that luteolin, quercetin and baicalein inhibited the secretion of granulocyte macrophage-colony stimulating factor by human cultured mast cells in response to crosslinkage of FceRI (Kimata et al., 2000a) and subsequently showed that these compounds also inhibited IgE-mediated tumor necrosis factor (TNF)- $\alpha$ and interleukin (IL)- 6 production by bone marrow-derived cultured murine mast cells (Kimata et al., 2000b). These findings thus indicate that flavonoids are inhibitors of chemical mediator release and cytokine production by mast cells and basophils. One of the characteristic features of allergic diseases is overproduction of IgE in response to environmental allergens. The differentiation of B cells into IgE-producing cells requires both the interaction of the CD40 ligand with CD40 and the action of IL-4 or IL-13 on B cells (Rosenwasser, 2011), which are provided with these signals by Th2 cells, basophils and mast cells (Gauchat et al., 1993). Basophils were then used to examine the effects of flavonoids on IL-4, IL-13 and CD40 ligand expression. It was found that fisetin suppressed in a dose-dependent fashion both IL-4 and IL-13 synthesis by allergen- or anti-IgE antibody-stimulated peripheral blood basophils and that the IC50 value of fisetin for inhibition of IL-4 synthesis was $5.8 \mu \mathrm{M}$ (Higa et al., 2003; Hirano et al., 2004). Fisetin also inhibited IL-4, IL-5 and IL-13 production by KU812 cells, a basophilic cell line, in response to the calcium ionophore, A23187 plus phorbol myristate acetate (PMA), but the suppressive effect of fisetin on IL-6, IL-8 and IL-1 $\beta$ synthesis was relatively weak (Higa et 
al., 2003). In order to determine the basic structure of the flavonoids that accounts for their inhibition of IL-4 production and to identify more active compounds, 45 kinds of flavones, flavonols and their related compounds were screened (Hirano et al., 2004; Kawai et al., 2007).

$\begin{array}{lccccccccccc} & 3 & 5 & 6 & 7 & 8 & 2 & 3 & 4 & 5 & 6 & \text { IC }_{50}(\mu \mathrm{M}) \\ \begin{array}{l}\text { Luteolin } \\ \text { Apigenin }\end{array} & \text { H } & \text { OH } & \text { H } & \text { OH } & \text { H } & \text { H } & \text { OH } & \text { OH } & \text { H } & \text { H } & 2.7 \\ \text { Fisetin } & \text { H } & \text { OH } & \text { H } & \text { OH } & \text { H } & \text { H } & \text { H } & \text { OH } & \text { H } & \text { H } & 3.1 \\ & \text { OH } & \text { H } & \text { H } & \text { OH } & \text { H } & \text { H } & \text { OH } & \text { OH } & \text { H } & \text { H } & 5.8 \\ \text { Compound 6 } & & & & & & & & & & & \\ \text { Scutellarein } & \text { H } & \text { OH } & \text { H } & \text { H } & \text { H } & \text { H } & \text { OH } & \text { OH } & \text { OH } & \text { H } & 11.4 \\ \text { Kaempferol } & \text { H } & \text { OH } & \text { OH } & \text { OH } & \text { H } & \text { H } & \text { H } & \text { OH } & \text { H } & \text { H } & 14.0 \\ \text { Quercetin } & \text { OH } & \text { OH } & \text { H } & \text { OH } & \text { H } & \text { H } & \text { H } & \text { OH } & \text { H } & \text { H } & 15.7 \\ \text { 7-Hydroxyflavone } & \text { OH } & \text { OH } & \text { H } & \text { OH } & \text { H } & \text { H } & \text { OH } & \text { OH } & \text { H } & \text { H } & 18.8 \\ & \text { H } & \text { H } & \text { H } & \text { OH } & \text { H } & \text { H } & \text { H } & \text { H } & \text { H } & \text { H } & 26.5 \\ \text { Myricetin } & & & & & & & & & & & \\ \text { Galangin } & \text { OH } & \text { OH } & \text { H } & \text { OH } & \text { H } & \text { H } & \text { OH } & \text { OH } & \text { OH } & \text { H } & >30 \\ \text { Baicalein } & \text { OH } & \text { OH } & \text { H } & \text { OH } & \text { H } & \text { H } & \text { H } & \text { H } & \text { H } & \text { H } & >30 \\ & \text { H } & \text { OH } & \text { OH } & \text { OH } & \text { H } & \text { H } & \text { H } & \text { H } & \text { H } & \text { H } & >30\end{array}$

Figure 2. Basic structure of flavonoids for inhibitory activity of IL-4 synthesis by basophils

Luteolin, apigenin and fisetin were found to be the strongest inhibitors with an IC50 value of 2.7-5.8 $\mu \mathrm{M}$ (Fig. 2). Quercetin and kaempferol are representative of flavonoids associated with a substantial daily intake and had an intermediate inhibitory effect on IL-4 synthesis with an IC50 value of 15.7-18.8 $\mu \mathrm{M}$, but myricetin showed no such effect. These analyses of structure-activity relationships revealed the fundamental structure required for the action. For maximal effect, hydroxylation in positions 7 and $4^{\prime}$ is essential while the presence of $\mathrm{OH}$ in either position 3 or 5 is also required. In addition, luteolin, apigenin and fisetin were found to suppress CD40 ligand expression by activated basophils and KU812 cells in a dosedependent manner, whereas myricetin even at $30 \mu \mathrm{M}$ did not have such an effect (Hirano et al., 2006). These inhibitory properties indicate that flavonoids such as luteolin, apigenin and fisetin are natural IgE inhibitors.

The aryl hydrocarbon receptor (AhR) is a ligand-activated transcriptional factor that mediates the toxic and biological actions of many aromatic environmental pollutants such as dioxins (Connor \& Aylward, 2006). An AhR-based in vitro bioassay for the dioxin [2,3,7,8tetrachlorodibenzo- $p$-dioxin (TCDD)] revealed that the flavonoids, apigenin, luteolin, baicalein, quercetin, kaempferol and myricetin had noticeable inhibitory effects on AhR activation with an $\mathrm{EC}_{70}$ value (equal to $70 \%$ of the maximal response to TCDD) of 1.9-5.1 $\mu \mathrm{M}$, while marked AhR activation was displayed by daidzein, resveratrol, naringenin and baicalein at higher concentrations (Amakura et al., 2008). Moreover, it has recently been 
shown that $\mathrm{AhR}$ is a regulator of differentiation of naïve CD4 positive T cells into effector T cell subsets (Marshall \& Kerkvliet, 2010), suggesting that flavonoids modulate immune functions through their binding to AhR.

\section{The relationship between flavonoid intake and the prevalence, incidence or severity of allergic diseases}

As mentioned previously, flavonoids are contained in vegetables, fruit, cereals and beverages. Epidemiological studies have reported that a high intake of fresh fruit and vegetables may provide protection against asthma (La Vecchia et al., 1998; Butland et al., 1999). The Mediterranean diet, which has high antioxidant content because of the preponderance of fruit, vegetables, legumes, nuts and wholegrain cereals, has been associated with a reduced likelihood of asthma, wheezing and allergic rhinitis in crosssectional studies of children (Chatzi et al., 2007; Garcia-Marcos et al., 2007; Tamay et al., 2007; De Batlle et al., 2008; Castro-Rodriguez et al., 2008). Shaheen et al reported that the results of a population-based case-control study of 607 cases and 864 controls in South London indicated that apple consumption and red wine intake were negatively associated with, respectively, asthma prevalence and severity, perhaps due to the protective effect of flavonoids (Shaheen et al., 2001), while the follow-up study made it clear that dietary intake of catechins, flavonols and flavones was not significantly associated with asthma prevalence and severity (Garcia et al., 2005). A cohort epidemiological study of 10,054 adults in Finland regarding the association between flavonoid intake and risk of several chronic diseases found that asthma incidence was lower for higher quercetin, naringenin, and hesperetin intakes (Knekt et al., 2002).

A study of 1,253 five-year-old children reported that maternal apple intake during their mothers' pregnancy was associated with beneficial results for ever wheeze, ever asthma and doctor-confirmed asthma (Willers et al., 2007). The Irish Lifeways Cross-Generation Cohort Study determined an association between high maternal fruit and vegetable intake during pregnancy and reduced likelihood of asthma in 632 three-year-old children (Fitzsimon et al., 2007). A third cohort study also demonstrated that wheeze and atopic sensitization in 460 children aged 6-7 years was less frequent if their mothers had followed a Mediterranean diet during pregnancy (Chatzi et al., 2008). Although there have been few reports of case-control or longitudinal studies examining direct associations between flavonoid intake and the prevalence or incidence of allergic diseases, the findings of the epidemiological studies mentioned here suggest that higher flavonoid intake is beneficial for protection against allergic diseases.

\section{Efficacy of flavonoids in allergic models}

The anti-allergic characteristics of flavonoids observed in vitro led to a study using NC/Nga mice to test whether intake of flavonoids might be effective for the prevention or the amelioration of allergic symptoms. NC/Nga mice spontaneously develop severe eczema, scratching behaviour and serum IgE elevation with aging under nonspecific pathogen-free 
conditions (Matsuda et al., 1997). To determine the preventive effect of flavonoids, the mice were orally given astragalin, kaempferol 3'glucoside $(1.5 \mathrm{mg} / \mathrm{kg})$, a major ingredient of flavonoid in persimmon leaf tea, or a control diet. Development of dermatitis with aging was observed in the control group and the severity of dermatitis was scored for evaluation. Oral intake of astragalin markedly prevented the appearance of the dermal symptoms, scratching behaviour and serum IgE elevation (Kotani et al., 2000). Moreover, when astragalin was administered to $\mathrm{NC} / \mathrm{Nga}$ mice after the appearance of dermatitis, it significantly diminished its severity (Matsumoto et al., 2002). It was subsequently demonstrated with this mouse model that administration of extracts from petals of Impatiens balsamina L., which contains flavonoids such as kaempferol 3-rutinoside and 2-hydroxy-1,4naphthoquinone as active gradients (Oku \& Ishiguro, 2001), of apigenin (Yano et al., 2009), or of baicalein (Yun et al., 2010) suppressed skin lesions. In an asthmatic mouse model sensitized with ovalbumin (OVA), it was demonstrated that oral administration of luteolin, even as little as $0.1 \mathrm{mg} / \mathrm{kg}$, led to a significant suppression of bronchial hyperreactivity and bronchoconstriction (Das et al., 2003). It was also found that nobiletin, a polymethoxyflavonoid, when given intraperitoneally to OVA-sensitized rats at a dose of 1.5 or $5 \mathrm{mg} / \mathrm{kg}$, reduced OVA-induced increases in eosinophils and eotaxin expression (Wu et al., 2006). In subsequent investigations, flavonoids such as quercetin, isoquercitrin, rutin, 3O-methylquercetin 5,7,3', $4^{\prime}$-O-tetraacetate, narirutin, apigenin, luteolin, sulfuretin, hesperdin, fisetin and kaempferol have been shown to suppress responses in various types of allergic animals (Makino et al., 2001; Fernandez et al., 2005; Rogerio et al., 2007; Jung et al., 2007; Jiang et al., 2007; Funaguchi et al., 2007; Yano et al., 2007; Cruz et al., 2008; Park et al., 2009; Choi et al., 2009; Li et al., 2010; Leemans et al., 2010; Shishebor et al., 2010; Song et al., 2010; Kim et al., 2011; Wu et al., 2011; Gong et al., 2012).

\section{Efficacy of flavonoids for patients with allergic rhinitis}

The aforementioned findings regarding the in vitro and in vivo anti-allergic properties of flavonoids strongly support the notion that an appropriate intake of flavonoids may constitute a complementary and alternative medicine and/or a preventive strategy for allergic diseases (Tanaka et al., 2003; Tanaka et al., 2004; Kawai et al., 2007; Tanaka et al., 2011; Singh et al., 2011). Indeed, the results of previous clinical trials using flavonoid extracts suggest that flavonoids have beneficial effects on allergic rhinitis (Takano et al., 2004; Kishi et al., 2005; Enomoto et al., 2006; Segawa et al., 2007; Yoshimura et al., 2007). The extracts examined were Perilla frutescens enriched with rosmarinic acid, apple polyphenols including procyanidins, or apple condensed tannin, catechin, epicatechin, phlorizin, and chlorogenic acid, hop water extract including quercetin and kaempferol glycosides, and tomato extract including mainly naringenin chalcone. However, the direct effect of flavonoids on allergic symptoms has remained unknown.

Enzymatically modified isoquercitrin (EMIQ) is a quercetin glycoside that consists of isoquercitrin and its maltooligosaccharides, and is manufactured from rutin through an enzymatic modification (Fig. 3) (Salim et al., 2004), which markedly enhances the absorption rate through the intestine. 
<smiles>O=c1c(O)c(-c2ccc(O)c(O)c2)oc2cc(O)cc(O)c12</smiles>

Quercetin<smiles>O=c1c(OC(Cl)Cl)c(-c2ccc(O)c(O)c2)oc2cc(O)cc(O)c12</smiles>

Enzymatically modified isoquercitrin EMIQ (n=1 8)

Figure 3. Enzymatically modified isoquercitrin is a quercetin glycoside.

This flavonoid is approved as a food additive in Japan and is used as an antioxidant for various commercially available food products such as beverages. Tests were performed in 2007, 2008 and 2009 to determine whether intake of EMIQ was effective for Japanese cedar pollinosis (Kawai et al., 2009; Hirano et al., 2009). Japanese cedar pollinosis is defined as an immunological response modulated by $\operatorname{IgE}$ and a seasonal (intermittent) allergic rhinoconjunctivitis caused by Japanese cedar pollen, characterized by nasal symptoms such as sneezing, rhinorrhea and nasal congestion and by ocular symptoms such as lacrimation, ocular itching and congestion (Okamoto et al., 2009).

In a parallel-group, double-blind, placebo-controlled study, volunteers with Japanese cedar pollinosis took two capsules of $50 \mathrm{mg}$ EMIQ or a placebo daily for 8 weeks during the pollen season. Severity of subjective symptoms was evaluated by a scoring system (Baba et al, 2002) with some modifications. The study in 2007 began after the pollen had dispersed and thus aimed at examining the therapeutic effect of EMIQ. During the entire study period, ocular symptom+medication and ocular symptom scores for the EMIQ group were significantly lower than those for the placebo group (Fig. 4), while symptom+medication and symptom scores were significantly reduced at week 4-5 compared to those for the placebo group (Kawai et al., 2009).

To examine the preventive effect of EMIQ on symptoms of pollinosis the next study in 2008 began 3 weeks before the first day of pollen dispersion. Ocular symptom+medication and ocular symptom scores were also significantly suppressed during the entire period and symptom+medication and symptom scores were also reduced at week 5-6 (Fig. 5) (Hirano et al., 2009).

Although these two studies did not show a statistically significant ameliorative effect on nasal symptoms, the 2009 study using $200 \mathrm{mg} /$ day of EMIQ for 4 weeks clearly demonstrated efficacy of EMIQ for reducing nasal symptoms (Fig. 6). 

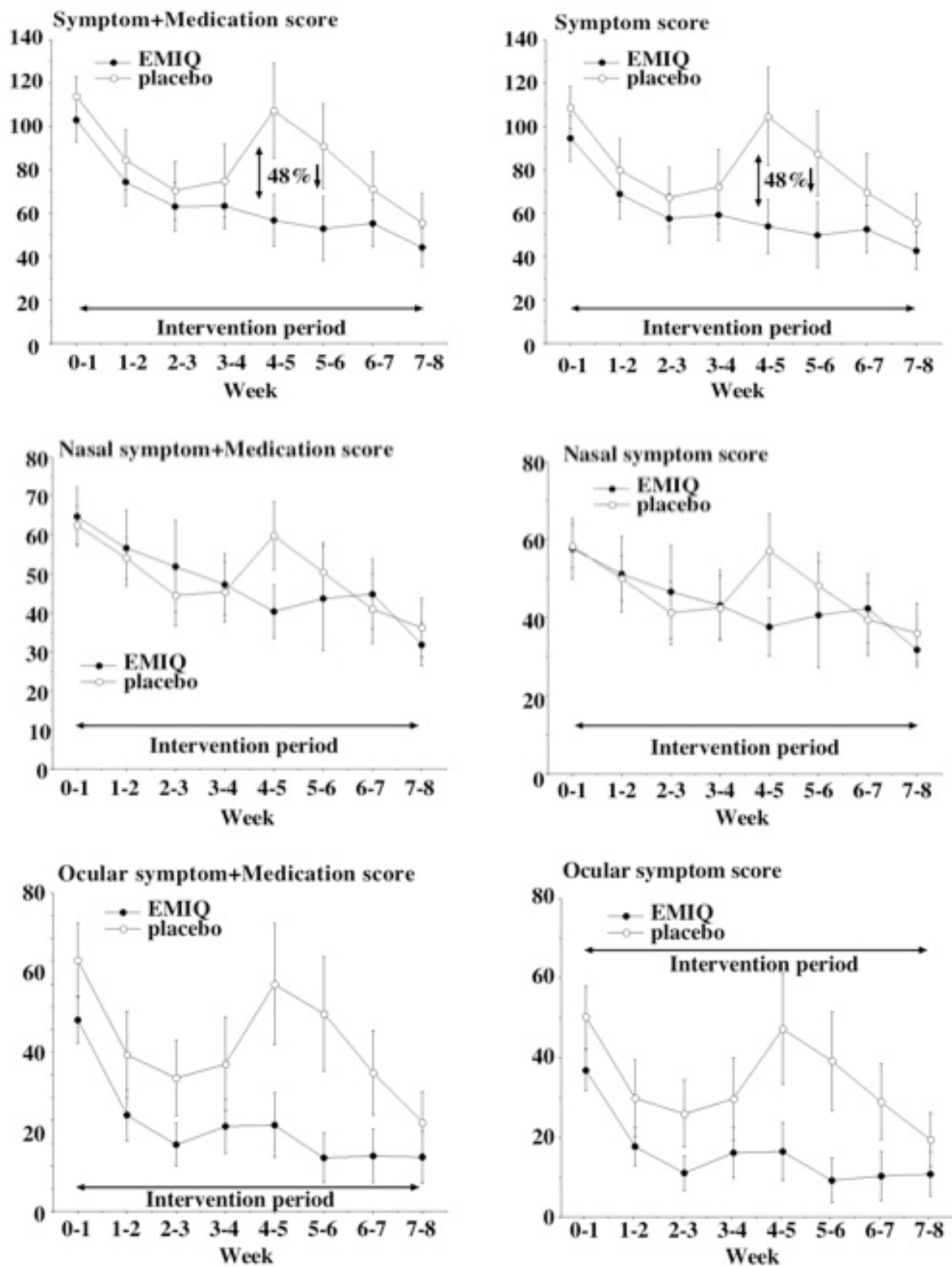

Figure 4. Efficacy of EMIQ on allergic symptoms caused by Japanese cedar pollinosis in 2007. The ameliorative effect was evaluated by total symptom (nasal+ocular symptom)+medication, total symptom, nasal symptom (sneezing, rhinorrhea and nasal obstruction)+medication, nasal symptom, ocular symptom (ocular itching, lacrimation and ocular congestion)+medication and ocular symptom scores. 

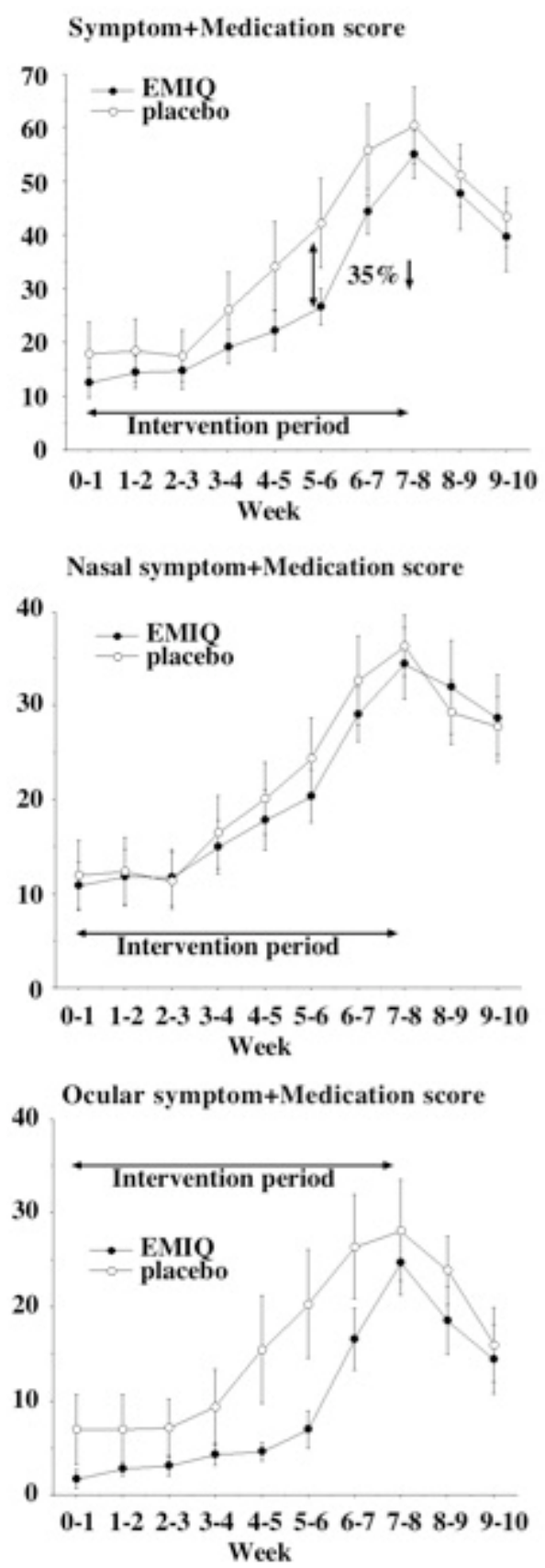

Symptom score

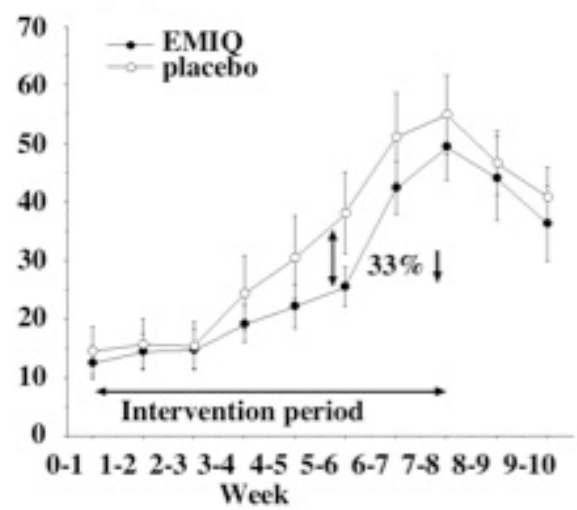

Nasal symptom score
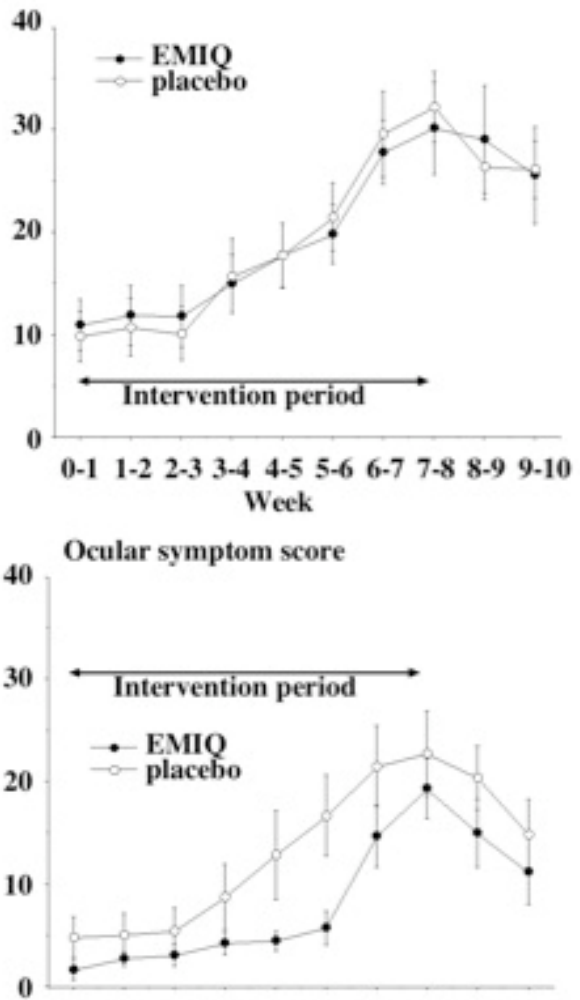

$\begin{array}{lllllllllll}0-1 & 1-2 & 2-3 & 3-4 & 4-5 & 5-6 & 6-7 & 7-8 & 8-9 & 9-10\end{array}$ Week

Figure 5. Efficacy of EMIQ on allergic symptoms caused by Japanese cedar pollinosis in 2008. 

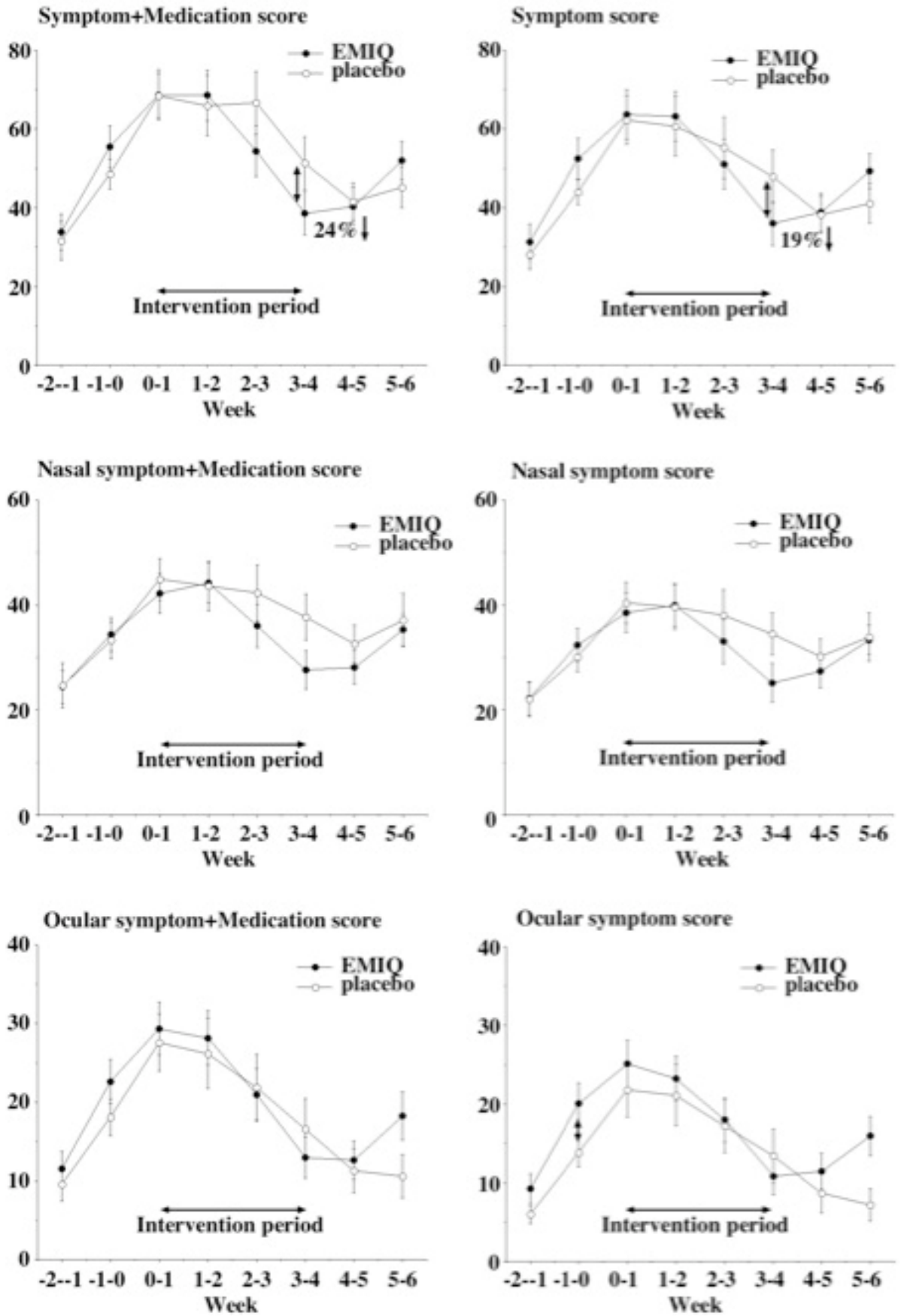

Figure 6. Efficacy of EMIQ on allergic symptoms caused by Japanese cedar pollinosis in 2009. 
Moreover, a recent study showed the beneficial action of silymarin on allergic rhinitis symptoms (Bakshaee et al., 2011), and clinical trials of pycnogenol, derived from the bark of the European coastal pine tree, including proanthocyanidines (Wilson et al., 2010), and of benifuuki green tea containing O-methylated catechin (Maeda-Yamamoto et al., 2009) demonstrated their ameliorative effects on seasonal allergic rhinitis symptoms.

\section{Flavonoid daily intake and content of foods}

Clinical trials of EMIQ involving patients with Japanese cedar pollinosis demonstrated that a daily intake of 100-200 mg of EMIQ is effective for the amelioration of symptoms. $100 \mathrm{mg}$ of EMIQ, a glycosylated quercetin, is equivalent to $34 \mathrm{mg}$ of quercetin. Results for the daily intake of flavonols plus flavones calculated in terms of the amounts of quercetin, kaempferol and myricetin, and, in some studies, with the addition of luteolin, apigenin and fisetin, have been reported in several countries (Tanaka et al., 2004). The total amount of these flavonoids varied from 2.6 to $68.2 \mathrm{mg} /$ day in the European Union, USA and Japan. The major flavonoid was quercetin, ranging from 14 to $100 \%$ of the total amount of flavonoids, followed by kaempferol and myricetin with an average intake of 0.1 to $5.9 \mathrm{mg} / \mathrm{day}$. An amount of 34 $\mathrm{mg} /$ day of quercetin is therefore tolerable and indeed there were no adverse events in the clinical trials. Recently, the U.S. Department of Agriculture (USDA) database for the flavonoid content of selected foods was published (USDA database, release 3, 2011). The database contains values for 500 food items and for 28 predominant monomeric dietary flavonoids that include quercetin, kaempferol, myricetin, apigenin and luteolin. It should be pointed out that most of the compounds in food are present in glycosylated forms, but this database converted the glycoside values into aglycone forms using conversion factors based on the molecular weight of the specific compounds to make data consistent across the database. EuroFIR-BASIS (European Food Information Resource - Bioactive Substances in Food Information System) is another database currently developed for bioactives that covers original content values for various polyphenols in plant-based foods (Gry et al., 2007). The more recently published Phenol-Explorer database includes content data for 502 polyphenols, flavonoids, phenolic acids, lignans, and stilbenes (Neveu et al., 2010; database URL: http://www.phenol-explorer.eu/; Perez-Jimenez et al., 2010). Over 60,000 composition data published since 1969 have been systemically collected, evaluated, and stored in this database and it contains information on glycosides and esters, whereas the USDA database pertains to data on aglycones. The Phenol-Explorer database was used to examine the intake of all individual polyphenols by a total of middle-aged 4,942 men and women in France (Perez-Jimenez et al., 2011). Mean total intake of flavonoids including proanthocyanidins, catechins, anthocyanins, flavonols, flavones, flavanones, theaflavins and dihydroflavonols was estimated at $506 \mathrm{mg}$ /day, with nonalcoholic beverages, fruit, alcoholic beverages, cocoa products, vegetables and cereals contributing 114, 172, 73, 90, 26 and 28 $\mathrm{mg} /$ day, respectively. Mean total intake of flavonols and flavones was 51 and $33 \mathrm{mg} /$ day, which is equivalent to 34 and $18 \mathrm{mg} /$ day of aglycones, respectively. The findings obtained with these databases are sure to make a significant contribution to the development of dietary treatment for allergic rhinitis. 


\section{Conclusion}

Allergy, a common disease worldwide, is the subject of growing concern because of its increasing rate of prevalence (Holgate, 1999; Eder et al, 2006). It has been suggested that dietary changes may contribute to this increase (McKeever \& Britton, 2004; Devereux \& Seaton, 2005; Devereux, 2006; Kozyrskyj et al., 2011; Nurmatov et al., 2011; Allan \& Devereux, 2011). Flavonoids have antioxidant, anti-allergic and immune-modulating properties and recent clinical trials have shown their beneficial effect on allergic rhinitis. Several extensive databases for the flavonoid content of major vegetables, fruit, cereals and beverages can thus be expected to contribute to the dietary management of allergic rhinitis. Whether an appropriate intake of flavonoids can ameliorate respiratory or dermal allergic symptoms and prevent the onset of allergic diseases thus constitutes an important issue for future studies.

\section{Author details}

Toshio Tanaka

Department of Respiratory Medicine, Allergy and Rheumatic Diseases,

Department of Clinical Application of Biologics, Osaka University Graduate School of Medicine, and Department of Immunopathology, WPI Immunology Frontier Research Center,

Osaka University, Osaka, Japan

\section{Acknowledgement}

The author thanks Dr. Mari Kawai, Dr. Toru Hirano, Dr. Shinji Higa, Ms. Mihoko Koyanagi, Ms. Tomoko Kai, Mr. Ryosuke Shimizu, Dr. Masamitsu Moriwaki, Dr. Yukio Suzuki, and Dr. Satoshi Ogino as collaborators for the clinical studies.

\section{References}

Allan, K. \& Devereux, G. (2011). Diet and asthma: nutrition implications from prevention to treatment. Journal of the American Dietetic Association, Vol.111, No.2, (February 2011), pp. 258-268.

Amakura, Y.; Tsutsumi, T.; Sasaki, K.; Nakamura, M.; Yoshida, T. \& Maitani, T. (2008). Influence of food polyphenols on aryl hydrocarbon receptor-signaling pathway estimated by in vitro bioassay. Phytochemistry, Vol.69, No.18, (December 2008), pp. 31173130.

Baba, K.; Konno, A. \& Takenaka, H. (2002). Epidemiology. in Okuda, M. (ed.), Guidelines for treatment of nasal allergy-perennial rhinitis and pollinosis. Life Science Publishing, Tokyo, 2002, pp. 8-11.

Bakhshaee, M.; Jabbari, F.; Hoseini, S.; Farid, R.; Sadeghian, M.H.; Rajati, M.; Mohamadpoor, A.H.; Movahhed, R. \& Zamani, M.A. (2011). Effect of silymarin in the treatment of 
allergic rhinitis. Otolaryngology-Head and Neck Surgery, Vol.145, No.6, (December 2011), pp. 904-909.

Bousquet, J.; Van Cauwenberge, P. \& Khaltaev, N.; Aria Workshop Group: World Health Organization. (2001). Allergic rhinitis and its impact on asthma. Journal of Allergy and Clinical Immunology, Vol.108(5 Suppl), (November 2001), pp. S147-334.

Butland, B.K.; Strachan, D.P. \& Anderson, H.R. (1999). Fresh fruit intake and asthma symptoms in young British adults: confounding or effect modification by smoking? European Respiratory Journal, Vol.13, No.4, (April 1999), pp. 744-750.

Calderon-Montano, J.M.; Burgos-Moron, E.; Perez-Guerrero, C. \& Lopez-Lazaro, M. (2011). A review on the dietary flavonoid kaempferol. Mini-Reviews in Medicinal Chemistry, Vol.11, No.4, (April 2011), pp. 298-344.

Castro-Rodriguez, J.A.; Garcia-Marcos, L.; Alfonseda Rojas, J.D.; Valverde-Molina, J. \& Sanchez-Solis, M. (2008). Mediterranean diet as a protective factor for wheezing in preschool children. The Journal of Pediatrics, Vol.152, No.6, (June 2008), pp. 823-828.

Chatzi, L.; Apostolaki, G.; Bibakis, I.; Skypala, I.; Bibaki-Liakou, V.; Tzanakis, N.; Kogevinas, M. \& Cullinan, P. (2007). Protective effect of fruits, vegetables and the Mediterranean diet on asthma and allegies among children in Crete. Thorax, Vol.62, No.8, (August 2007), pp. 677-683.

Chatzi, L.; Torrent, M.; Romieu, I.; Garcia-Esteban, R.; Ferrer, C.; Vioque, J.; Kogevinas, M. \& Sunyer, J. (2008). Mediterranean diet in pregnancy is protective for wheeze and atopy in childhood. Thorax, Vol.63, No.6, (June 2008), pp. 507-513.

Cheong, H.; Ryu, S.Y.; Oak, M.H.; Cheon, S.H.; Yoo, G.S. \& Kim, K.M. (1998). Studies of structure activity relationship of flavonoids for the anti-allergic actions. Archives of Pharmacal Research, Vol.21, No.4, (August 1998), pp. 478-480.

Chirumbolo, S. (2010). The role of quercetin, flavonols and flavones in modulating inflammatory cell function. Inflammatory \& Allergy Drug Targets, Vol.9, No.4, (September 2010), pp. 263-285.

Choi, J.R.; Lee, C.M.; Jung, I.D.; Lee, J.S.; Jeong, Y.I.; Chang, J.H.; Park, H.J.; Choi, I.W.; Kim, J.S.; Shin, Y.K.; Park, S.N. \& Park, Y.M. (2009). Apigenin protects ovalbumin-induced asthma through the regulation of GATA-3 gene. International Immunopharmacology, Vol.9, No.7-8, (July 2009), pp. 918-924.

Connor, K.T. \& Aylward, L.L. (2006). Human response to dioxin: aryl hydrocarbon receptor (AhR) molecular structure, function, and dose-response data for enzyme induction indicate an impaired human AhR. Journal of Toxicology and Environmental Health, Part B: Critical Reviews, Vol.9, No.2, (December 2006), pp. 147-171.

Cruz, E.A.; Da-Silva, S.A.; Muzitano, M.F.; Silva, P.M.; Costa, S.S. \& Rossi-Bergmann, B. (2008). Immunomodulatory pretreatment with Kalanchoe pinnata extract and its quercitrin flavonoid effectively protects mice against fatal anaphylactic shock. International Immunopharmacology, Vol.8, No.12, (December 2008), pp. 1616-1621.

Das, M.; Ram, A. \& Ghosh, B. (2003). Luteolin alleviates bronchoconstriction and airway hyperreactivity in ovalbumin sensitized mice. Inflammation Research, Vol.52, No.3, (March 2003), pp. 101-106. 
De Batlle, J.; Garcia-Aymerich, J.; Barraza-Villarreal, A.; Anto, J.M. \& Romieu, I. (2008). Mediterranean diet is associated with reduced asthma and rhinitis in Mexican children. Allergy, Vol.63, No.10, (October 2008), pp. 1310-1316.

Devereux, G. \& Seaton, A. (2005). Diet as a risk factor for atopy and asthma. Journal of Allergy and Clinical Immunology, Vol.115, No.6, (June 2005), pp. 1109-1117.

Devereux, G. (2006). The increase in the prevalence of asthma and allergy: food for thought. Nature Reviews Immunology, Vol.6, No.11, (November 2006), pp. 869-874.

Eder, W.; Ege, M.J. \& von Mutius, E. (2006). The asthma epidemic. The New England Journal of Medicine, Vol.355, No.21, (November 2006), pp. 2226-2235.

Enomoto, T.; Nagasako-Akazome, Y.; Kanda, T.; Ikeda, M. \& Dake, T. (2006). Clinical effects of apple polyphenols on persistent allergic rhinitis: a randomized double-blind placebocontrolled parallel arm study. Journal of Investigational Allergolology and Clinical Immunology, Vol.16, No.5, (October 2006), pp. 283-289.

Fernandez, J.; Reyes, R.; Ponce, H.; Oropeza, M.; Vancalsteren, M.R.; Jankowski, C. \& Campos, M.G. (2005). Isoquercitrin from Argemone platyceras inhibits carbachol and leukotriene D4-induced contraction in guinea-pig airways. European Journal of Pharmacology, Vol.522, No.1-3, (October 2005), pp. 108-115.

Fewtrell, C.M. \& Gomperts, B.D. (1997). Effect of flavone inhibitors on transport ATPases on histamine secretion from rat mast cells. Nature, Vol.265, No.5595, (February 1997), pp. 635-636.

Fitzsimon, N.; Fallon, U.B.; O’Mahony, D.; Loftus, B.G.; Bury, G.; Murphy, A.W. \& Kelleher, C.C.; Lifeways Cross Generation Cohort Study Steering Group. (2007). Mothers' dietary patterns during pregnancy and the risk of asthma symptoms in children at 3 years. Irish Medical Journal, Vol.100, No.8 suppl, (September 2007), pp. 27-32.

Funaguchi, N.; Ohno, Y.; La, B.L.; Asai, T.; Yuhgetsu, H.; Sawada, M.; Takemura, G.; Minatoguchi, S.; Fujiwara, T. \& Fujiwara, H. (2007). Narirutin inhibits airway inflammation in an allergic mouse model. Clinical and Experimental Pharmacology and Physiology, Vol.34, No.8, (August 2007), pp. 766-770.

Garcia-Marcos, L.; Canflanca, I.M.; Garrido, J.B.; Varela, A.L.; Garcia-Hernandez, G.; Guillen Grim, F.; Gonzalez-Diaz, C.; Carvajal-Uruena, I.; Arnedo-Pena, A.; Busquets-Monge, R.M.; Morales Suarez-Varela, M. \& Blanco-Quiros, A. (2007). Relationship of asthma and rhinoconjunctivitis with obesity, exercise and Mediterranean diet in Spanish schoolchildren. Thorax, Vol.62, No.6, (June 2007), pp. 503-508.

Garcia, V.; Arts, I.C.; Sterne, J.A.; Thompson, R.L. \& Shaheen, S.O. (2005). Dietary intake of flavonoids and asthma in adults. European Respiratory Journal, Vol.26, No.3, (September 2005), pp. 449-452.

Gauchat, J.F.; Henchoz, S.; Mazzei, G.; Aubry, J.P.; Brunner, T.; Blasey, H.; Life, P.; Talabot, D.; Flores-Romo, L.; Thompson J.; Kishi, K.; Butterfield, J.; Dahinden, C. \& Bonnefoy, J.Y. (1993). Induction of human IgE synthesis in B cells by mast cells and basophils. Nature, Vol.365, No.6444, (September 1993), pp. 340-343.

Gong, J.H.; Shin, D.; Han, S.Y.; Kim, J.L. \& Kang, Y.H. (2012). Kaempferol suppresses eosinophil infiltration and airway inflammation in airway epithelial cells and in mice with allergic asthma. The Journal of Nutrition, Vol.142, No.1, (January 2012), pp. 47-56. 
Grammatikos, A.P. (2008). The genetic and environmental basis of atopic diseases. Annals of Medicine, Vol.40, No.7, (September 2008), pp. 482-495.

Greiner, A.N.; Hellings, P.W.; Rotiroti, G. \& Scadding, G.K. (2011). Allergic rhinitis. Lancet, Vol.378, No.9809, (December 2011), pp. 2112-2122.

Gry, J.; Black, L.; Eriksen, F.D.; Pilegaard, K.; Plumb, J.; Plumb, J.; Rhodes, M.; Sheehan, D.; Kiely, M. \& Kroon, P.A. (2007). EuroFIR-BASIS - a combined composition and biological activity database for bioactive compounds in plant-based foods. Trends in Food Science \& Technology, Vol.18, No.8, (August 2007), pp. 434-444.

Harborne, J.B. \& Williams, C.A. (2000). Advances in flavonoid research since 1992. Phytochemistry, Vol.55, No.6, (November 2000), pp. 481-504.

Higa, S.; Hirano, T.; Kotani, M.; Matsumoto, M.; Fujita, A.; Suemura, M.; Kawase, I. \& Tanaka, T. (2003). Fisetin, a flavonol, inhibits TH2-type cytokine production by activated human basophils. Journal of Allergy and Clinical Immunology, Vol.111, No.6, (June 2003), pp. 1299-1306.

Hirano, T.; Higa, S.; Arimitsu, J.; Naka, T.; Shima, Y.; Ohshima, S.; Fujimoto, M.; Yamadori, T.; Kawase, I. \& Tanaka, T. (2004). Flavonoids such as luteolin, fisetin and apigenin are inhibitors of interleukin-4 and interleukin-13 production by activated human basophils. International Archives of Allergy and Immunology, Vol.134, No.2, (June 2004), pp. 135-140.

Hirano, T.; Arimitsu, J.; Higa, S.; Naka, T.; Ogata, A.; Shima, Y.; Fujimoto, M.; Yamadori, T.; Ohkawara, T.; Kuwahara, Y.; Kawai, M.; Kawase, I. \& Tanaka, T. (2006). Luteolin, a flavonoid, inhibits CD40 ligand expression by activated human basophils. International Archives of Allergy and Immunology, Vol.140, No.2, (April 2006), pp. 150-156.

Hirano, T.; Kawai, M.; Arimitsu, J.; Ogawa, M.; Kuwahara, Y.; Hagihara, K.; Shima, Y.; Narazaki, M.; Ogata, A.; Koyanagi, M.; Kai, T.; Shimizu, R.; Moriwaki, M.; Suzuki, Y.; Ogino, S.; Kawase, I. \& Tanaka, T. (2009). Preventative effect of a flavonoid, enzymatically modified isoquercitrin on ocular symptoms of Japanese cedar pollinosis. Allergology International, Vol.58, No.3, (September 2009), pp. 373-382.

Ho, S.M. (2010). Environmental epigenetics of asthma: an update. Journal of Allergy and Clinical Immunology, Vol.126, No.3, (September 2010), pp. 453-465.

Holgate, S.T. (1999). The epidemic of allergy and asthma. Nature, Vol.402, No.6760 Suppl, (November 1999), pp. B2-4.

Hollman, P.C. \& Katan, M.B. (1999). Dietary flavonoids: intake, health effects and bioavailability. Food \& Chemical Toxicology, Vol.37, No.9-10, (September-October 1999), pp. 937-942.

Horiguchi, S. \& Saito, Y. (1964). Discovery of Japanese cedar pollinosis in Nikko, Ibaraki prefecture. Arerugi, Vol.13, (January-February 1964), pp. 16-18.

Jiang, J.S.; Chien, H.C.; Chen, C.M.; Lin, C.N. \& Ko, W.C. (2007). Potent suppressive effects of 3-O-methylquercetin 5,7,3', $4^{\prime}$-O-tetraacetate on ovalbumin-induced airway hyperresponsiveness. Planta Medica, Vol.73, No.11, (September 2007), pp. 1156-1162.

Jung, C.H.; Lee, J.Y.; Cho, C.H. \& Kim, C.J. (2007). Anti-asthmatic action of quercetin and rutin in conscious guinea-pigs challenged with aerosolized ovalbumin. Archives of Pharmacal Research, Vol.30, No.12, (December 2007), pp. 1599-1607. 
Kaneko, Y.; Motohashi, Y.; Nakamura, H.; Endo, T. \& Eboshiba, A. (2005). Increasing prevalence of Japanese cedar pollinosis: a meta-regression analysis. International Archives of Allergy and Immunology, Vol.136, No.4, (April 2005), pp. 365-371.

Kawai, M.; Hirano, T.; Higa, S.; Arimitsu, J.; Maruta, M.; Kuwahara, Y.; Ohkawara, T.; Hagihara, K.; Yamadori, T.; Shima, Y.; Ogata, A.; Kawase, I. \& Tanaka, T. (2007). Flavonoids and related compounds as anti-allergic substances. Allergology International, Vol.56, No.2, (June 2007), pp. 113-123.

Kawai, M.; Hirano, T.; Arimitsu, J.; Higa, S.; Kuwahara, Y.; Hagihara, K.; Shima, Y.; Narazaki, M.; Ogata, A.; Koyanagi, M.; Kai, T.; Shimizu, R.; Moriwaki, M.; Suzuki, Y.; Ogino, S.; Kawase, I. \& Tanaka, T. (2009). Enzymatically modified isoquercitrin, a flavonoid, on symptoms of Japanese cedar pollinosis: a randomized double-blind placebo-controlled trial. International Archives of Allergy and Immunology, Vol.149, No.4, (July 2009), pp. 359-368.

Kim, S.H.; Kim, B.K. \& Lee, Y.C. (2011). Antiasthmatic effects of hesperdin, a potential Th2 cytokine antagonist, in a mouse model of allergic asthma. Mediators of Inflammation, (May 2011), 2011;485402.

Kimata, M.; Shichijo, M.; Miura, T.; Serizawa, I.; Inagaki, N. \& Nagai, H. (2000a). Effects of luteolin, quercetin and baicalein on immunoglobulin E-mediated mediator release from human cultured mast cells. Clinical E Experimental Allergy, Vol.30, No.4, (April 2000), pp. 501-508.

Kimata, M.; Inagaki, N. \& Nagai, H. (2000b). Effects of luteolin and other flavonoids on IgEmediated allergic reactions. Plant Medicine, Vol.66, No.1, (February 2000), pp. 25-29.

Kishi, K.; Saito, M.; Saito, T.; Kumemura, M.; Okamatsu, H.; Okita, M. \& Takazawa, K. (2005). Clinical efficacy of apple polyphenol for treating cedar pollinosis. Bioscience, Biotechnology, and Biochemistry, Vol.69, No.4, (April 2005), pp. 829-832.

Knekt, P.; Kumpulainen, J.; Jarvinen, R.; Rissanen, H.; Heliovaara, M.; Reunanen, A.; Hakulinen, T. \& Aromaa A. (2002). Flavonoid intake and risk of chronic diseases. The American Journal of Clinical Nutrition, Vol.76, No.3, (September 2002), pp. 560-568.

Kotani, M.: Matsumoto, M.; Fujita, A.; Higa, S.; Wang, W.; Suemura, M.; Kishimoto, T. \& Tanaka, T. (2000). Persimmon leaf extract and astragalin inhibit development of dermatitis and IgE elevation in NC/Nga mice. Journal of Allergy and Clinical Immunology, Vol.106(1 Pt 1), (July 2000), pp. 159-166.

Kouda, K.; Tanaka, T.; Kouda, M.; Takeuchi, H.; Takeuchi, A.; Nakamura, H. \& Takigawa, M. (2000). Low-energy diet in atopic dermatitis patients: clinical findings and DNA damage. Journal of Physiological Anthropology and Applied Human Science, Vol.19, No.5, (September 2000), pp. 225-228.

Kozyrskyj, A.L.; Bahreinian, S. \& Azad, M.B. (2011). Early life exposures: impact on asthma and allergic disease. Current Opinion in Allergy and Clinical Immunology, Vol.11, No.5, (October 2011). pp. 400-406.

La Vecchia, C.; Decarli, A. \& Pagano, R. (1998). Vegetable consumption and risk of chronic disease. Epidemiology, Vol.9, No.2, (March 1998), pp. 208-210. 
Lee, T.P.; Matteliano, M.L. \& Middleton, E.J. (1982). Effect of quercetin on human polymorphonuclear leukocyte lysosomal enzyme release and phospholipid metabolism. Life Sciences, Vol.31, No.24, (December 1982), pp. 2765-2774.

Leemans, J.; Cambier, C.; Chandler, T.; Billen, F.; Clercx, C.; Kirschvink, N. \& Gustin, P. (2010). Prophylactic effects of omega-3 polyunsaturated fatty acids and luteolin on airway hyperresponsiveness and inflammation in cats with experimentally-induced asthma. The Veterinary Journal, Vol.184, No.1, (April 2010), pp. 111-114.

Li, R.R.; Pang, L.L.; Du, Q.; Shi, Y.; Dai, W.J. \& Yin, K.S. (2010). Apigenin inhibits allergeninduced airway inflammation and switches immune response in a murine model of asthma. Immunopharmacology and Immunotoxicology, Vol.32, No.3, (September 2010), pp. 364-370.

Maeda-Yamamoto, M.; Ema, K.; Monobe, M.; Shibuichi, I.; Shinoda, Y.; Yamamoto, T. \& Fujisawa, T. (2009). The efficacy of early treatment of seasonal allergic rhinitis with benifuuki green tea containing $O$-methylated catechin before pollen exposure: an open randomized study. Allergology International, Vol.58, No.3, (September 2009), pp. 437-444.

Makino, T.; Furuta, Y.; Fujii, H.; Nakagawa, T.; Wakushima, H.; Saito, K. \& Kano, Y. (2001). Effect of oral treatment of Perilla frutescens and its constituents on type-1 allergy in mice. Biological and Pharmaceutical Bulletin, Vol.24, No.10, (October 2001), pp. 1206-1209.

Manach, C.; Scalbert, A.; Morand, C.; Remesy, C.; Jimenez, L. (2004). Polyphenols: food sources and bioavailability. The American Journal of Clinical Nutrition, Vol.79, No.5, (May 2004), pp. 727-747.

Marshall, N.B. \& Kerkvliet, N.I. (2010). Dioxin and immune regulation: emerging role of aryl hydrocarbon receptor in the generation of regulatory T cells. Annals of the New York Academy of Sciences, Vol.1183, (January 2010), pp. 25-37.

Matsuda, H.; Watanabe, N.; Geba, G.P.; Sperl, J.; Tsudzuki, M.; Hiroi, J.; Matsumoto, M.; Ushio, H.; Saito, S.; Askenase, P.W. \& Ra, C. (1997). Development of atopic dermatitislike skin lesion with IgE hyperproduction in NC/Nga mice. International Immunology, Vol.9, No.3, (May 1997), pp. 461-466.

Matsumoto, M.; Kotani, M.; Fujita, A.; Higa, S.; Kishimoto, T.; Suemura, M. \& Tanaka, T. (2002). Oral administration of persimmon leaf extract ameliorates skin symptoms and transepidermal water loss in atopic dermatitis model mice, NC/Nga. British Journal of Dermatology, Vol.146, No.2, (February 2002), pp. 221-227.

McKeever, T.M. \& Britton, J. (2004). Diet and asthma. American Journal of Respiratory Critical Care of Medicine, Vol.170, No.7, (October 2004), pp. 725-729.

Middleton, E.J.; Drzewiecki, G. \& Krishnarao, D. (1981). Quercetin: an inhibitor of antigeninduced human basophil histamine release. The Journal of Immunology, Vol.127, No.2, (August 1981), pp. 546-550.

Middleton, E.J. \& Kandaswami, C. (1992). Effects of flavonoids on immune and inflammatory cell functions. Biochemical Pharmacology, Vol.43, No.6, (March 1992), pp. 1167-1179.

Middleton, E.J.; Kandaswari, C. \& Theoharides, T.C. (2000). The effects of plant flavonoids on mammalian cells: implications for inflammation, heart disease, and cancer. Pharmacological Reviews, Vol.52, No.4, (December 2000), pp. 673-751. 
Neveu, V.; Perez-Jimenez, J.; Vos, F.; Crespy, V.; Du Chaffaut, L.; Mennen, L.; Knox, C.; Eisner, R.; Cruz, J.; Wishart, D. \& Scalbert, A. (2010). Phenol-Explorer: an online comprehensive database on polyphenol contents in foods. Database (Oxford), 2010;2010:bap024.

Nolte, H.; Backer, V. \& Porsbjerg, C. (2001). Environmental factors as a cause for the increase in allergic disease. Annals of Allergy, Asthma \& Immunology, Vol.87(6 Suppl 3), (December 2001), pp. 7-11.

Nurmatov, U.; Devereux, G. \& Sheikh, A. (2011). Nutrients and foods for the primary prevention of asthma and allergy: systemic review and meta-analysis. Journal of Allergy and Clinical Immunology, Vol.127, No.3, (March 2011), pp. 724-733.

Okamaoto, Y.; Horiguchi, S.; Yamamoto, H.; Yonekura, S. \& Hanazawa T. (2009). Present situation of cedar pollinosis in Japan and its immune responses. Allergology International, Vol.58, No.2, (March 2009), pp. 155-162.

Oku, H. \& Ishiguro, K. (2001). Antipruritic and antidermatitic effects of extract and compounds of Impatiens balsamina L. in atopic dermatitis model NC mice. Phytotherapy Research, Vol.15, No.6, (September 2001), pp. 506-510.

Ozdoganoglu, T. \& Songu, M. (2012). The burden of allergic rhinitis and asthma. Therapeutic Advances in Respiratory Disease, Vol.6, No.1, (January 2012), pp. 11-23.

Park, H.J.; Lee, C.M.; Jung, I.D.; Lee, J.S.; Jeong, Y.I.; Chang, J.H.; Chun, S.H.; Kim, M.J.; Choi, I.W.; Ahn, S.C.; Shin, Y.K.; Yeom, S.R. \& Park, Y.M. (2009). Quercetin regulates Th1/Th2 balance in a murine model of asthma. International Immunopharmacology, Vol.9, No.3, (March 2009), pp. 261-267.

Perez-Jimenez, J.; Neveu, V.; Vos, F. \& Scalbert, A. (2010). Systematic analysis of the content of 502 polyphenols in 452 foods and beverages: an application of the Phenol-Explorer database. Journal of Agricultural and Food Chemistry, Vol.58, No.8, (April 2010), pp. 49594969.

Perez-Jimenez, J.; Fezeu, L.; Touvier, M.; Arnault, N.; Manach, C.; Hercberg, S.; Galan, P. \& Scalbert, A. (2011). Dietary intake of 337 polyphenols in French adults. The American Journal of Clinical Nutrition, Vol.93, No.6, (June 2011), pp. 1220-1228.

Rogerio, A.P.; Kanashiro, A.; Fontanari, C.; da Silva, E.V.; Lucisano-Valim, Y.M.; Soares, E.G. \& Faccioli, L.H. (2007). Anti-inflammatory activity of quercetin and isoquercitrin in experimental murine allergic asthma. Inflammation Research, Vol.56, No.10, (October 2007), pp. 402-408.

Rosenwasser, L.J. (2011). Mechanisms of IgE inflammation. Current Allergy and Asthma Reports, Vol.11, No.2, (April 2011), pp. 178-183.

Russo, M.; Spagnuolo, C.; Tedesco, I.; Bilotto, S. \& Russo, G.L. (2012). The flavonoid quercetin in disease prevention and therapy: facts and fancies. Biochemical Pharmacology, Vol.83, No.1, (January 2012), pp. 6-15.

Salim, E.I.; Kaneko, M.; Wanibuchi, H.; Morimura, K. \& Fukushima, S. (2004). Lack of carcinogenicity of enzymatically modified isoquercitrin in F344/DuCrj rats. Food and Chemical Toxicology, Vol.42, No.12, (December 2004), pp. 1949-1969. 
Sealbert, A.; Manach, C.; Morand, C.; Remesy, C. \& Jimenez, L. (2005). Dietary polyphenols and the prevention of diseases. Critical Reviews in Food Science and Nutrition, Vol.45, No.4, (April 2005), pp. 287-306.

Segawa, S.; Takata, Y.; Wakita, Y.; Kaneko, T.; Kaneda, H.; Watari, J.; Enomoto, T. \& Enomoto, T. (2007). Clinical effects of a hop water extract on Japanese cedar pollinosis during the pollen season: a double-blind, placebo-controlled trial. Bioscience, Biotechnology, and Biochemistry, Vol.71, No.8, (October 2007), pp. 1955-1962.

Shaheen, S.O.; Sterne, J.A.; Thompson, R.L.; Songhurst, C.E.; Margetts, B.M. \& Burney, P.G. (2001). Dietary antioxidants and asthma in adults: population-based case-control study. American Journal of Respiratory and Critical Care Medicine, Vol.164(10 Pt 1), pp. 1823-1828.

Shishebor, F.; Behroo, L.; Ghafouriyan Broujerdnia, M.; Namjoyan, F. \& Latifi, S.M. (2010). Quercetin effectively quells peanut-induced anaphylactic reactions in the peanut sensitized rats. Iranian Journal of Allergy, Asthma and Immunology, Vol.9, No.1, (March 2010), pp 27-34.

Singh, A.; Holvoet, A. \& Mercenier, A. (2011). Dietary polyphenols in the prevention and treatment of allergic diseases. Clinical \& Experimental Allergy, Vol.41, No.10, (October 2011), pp. 1346-1359.

Song, M.Y.; Jeong, G.S.; Lee, H.S.; Kwon, K.S.; Lee, S.M.; Park, J.W.; Kim, Y.C. \& Park, B.H. (2010). Sulfuretin attenuates allergic airway inflammation in mice. Biochemical and Biophysical Research Communications, Vol.400, No.1, (September 2010). pp. 83-88.

Stone, K.D.; Prussin, C. \& Metcalfe, D.D. (2010). IgE, mast cells, basophils, and eosinophils. Journal of Allergy and Clinical Immunology, Vol.125(2 Suppl 2), (February 2010), pp. S7380.

Takano, H.; Osakabe, N.; Sanbongi, C.; Yanagisawa, R.; Inoue, K.; Yasuda, A.; Natsume, M.; Baba, S.; Ichiishi, E. \& Yoshikawa, T. (2004). Extract of Perilla frutescens enriched for rosmarinic acid, a polyphenolic phytochemical, inhibits seasonal allergic rhinoconjunctivitis in humans. Experimental Biology and Medicine, Vol.229, No.3, (March 2004), pp. 247-254.

Tamay, Z.; Akcay, A.; Ones, U.; Guler, N.; Kilic, G. \& Zencir, M. (2007). Prevalence and risk factors for allergic rhinitis in primary school children. International Journal of Pediatric Otorhinolaryngology, Vol.71, No.3, (March 2007), pp. 463-471.

Tanaka, T.; Kouda, K.; Kotani, M.; Takeuchi, A.; Tabei, T.; Masamoto, Y.; Nakamura, H.; Takigawa, M.; Suemura, M.; Takeuchi, H. \& Kouda, M. (2001). Vegetarian diet ameliorates symptoms of atopic dermatitis through reduction of the number of peripheral eosinophils and of PGE2 synthesis by monocytes. Journal of Physiological Anthropology and Applied Human Science, Vol.20, No.6, (November 2001), pp. 353-361.

Tanaka, T.; Higa, S.; Hirano, T.; Kotani, M.; Matsumoto, M.; Fujita, A. \& Kawase, I. (2003). Flavonoids as potential anti-allergic substances. Current Medicinal Chemistry-AntiInflammatory \& Anti-Allergy Agents, Vol.2, No.1, (March 2003), pp. 57-65.

Tanaka, T.; Higa, S.; Hirano, T.; Arimitsu, J.; Naka, T.; Shima, Y.; Ohshima, S.; Fujimoto, M.; Yamadori, T. \& Kawase, I. (2004). Is an appropriate intake of flavonoids a prophylactic means or complementary and alternative medicine for allergic diseases? Recent Research Developmental Allergy \& Clinical Immunology, Vol.5, (February 2004), pp. 1-14. 
Tanaka, T.; Hirano, T.; Kawai, M.; Arimistu, J.; Hagihara, K.; Ogawa, M.; Kuwahara, Y.; Shima, Y.; Narazaki, M.; Ogata, A. \& Kawase, I. (2011). Flavonoids, natural inhibitors of basophil activation. Paul, K. Vellis, (ed.), Basophil Granulocytes, Nova Science Publishers, Inc., New York, 2011; Chapter 4, pp 61-72.

USDA database for the flavonoid content of selective foods. Release 3. (2011). Prepared by Seema Bhagwat, David B. Haytowitz and Joanne M. Holden. U.S. Department of Agriculture. (September 2011), URL: http://www.ars.usda.gov/nutrientdata

Visioli, F.; De La Lastra, C.A.; Andres-Lacueva, C.; Aviram, M.; Calhau, C.; Cassano, A.; D’Archivio, M.; Faria, A.; Fave, G.; Fogliano, V.; Llorach, R.; Vitaglione, P.; Zoratti, M. \& Edeas, M. (2011). Polyphenols and human health: a prospectus. Critical Reviews in Food Sciences and Nutrition, Vol.51, No.6, (July 2011), pp. 524-546.

Willers, S.M.; Devereux, G.; Craig, L.C.; McNeill, G.; Wijga, A.H.; Abou, El-Magd, W.; Turner, S.W.; Helms, P.J. \& Seaton, A. (2007). Maternal food consumption during pregnancy and asthma, respiratory and atopic symptoms in 5-year-old children. Thorax, Vol.62, No.9, (September 2007), pp. 773-779.

Williams, C.A. \& Grayer, R.J. (2004). Anthocyanins and other flavonoids. Natural Product Reports, Vol.21, No.4, (August 2004), pp. 539-573.

Wilson, D.; Evans, M.; Guthrie, N.; Sharma, P.; Baisley, J.; Schonlau, F. \& Burki, C. (2010). A randomized, double-blind, placebo-controlled exploratory study to evaluate the potential of pycnogenol for improving allergic rhinitis symptoms. Phytotherapy Research, Vol.24, No.8, (August 2010), pp. 1115-1119.

Wu, M.Y.; Hung, S.K. \& Fu, S.L. (2011). Immunosuppressive effects of fisetin in ovalbumininduced asthma through inhibition of NF-kB activity. Journal of Agricultural and Food Chemistry, Vol.59, No.19, (October 2011), pp. 10496-10504.

Wu, Y.Q.; Zhou, C.H.; Tao, J. \& Li, S.N. (2006). Antagonistic effects of nobiletin, a polymethoxyflavonoid, on eosinophilic airway inflammation of asthmatic rats and relevant mechanisms. Life Sciences, Vol.78, No.23, (May 2006), pp. 2689-2696.

Yano, S.; Umeda, D.; Yamashita, S.; Ninomiya, Y.; Sumida, M.; Fujimura, Y.; Yamada, K. \& Tachibana, H. (2007). Dietary flavones suppress IgE and Th2 cytokines in OVA-immunized BALB/c mice. European Journal of Nutrition, Vol.46, No.5, (August 2007), pp. 257-263.

Yano, S.; Umeda, D.; Yamashita, S.; Yamada, K. \& Tachibana, H. (2009). Dietary apigenin attenuates the development of atopic dermatitis-like skin lesions in NC/Nga mice. The Journal of Nutritional Biochemistry, Vol.20, No.11, (November 2009), pp. 876-881.

Yoshimoto, T.; Furukawa, M.; Yamamoto, S.; Horie, T. \& Watanabe-Kohno, S. (1983). Flavonoids: potent inhibitors of arachidonate 5-lipoxygenase. Biochemical and Biophysical Research Communications, Vol.116, No.2, (October 1983), pp. 612-618.

Yoshimura, M.; Enomoto, T.; Dake, Y.; Okuno, Y.; Ikeda, H.; Cheng, L. \& Obata, A (2007). An evaluation of the clinical efficacy of tomato extract for perennial allergic rhinitis. Allergology International, Vol.56, Vol.3, (September 2007), pp. 225-230.

Yun, M.Y.; Yang, J.H.; Kim, D.K.; Cheong, K.J.; Song, H.H.; Kim, D.H.; Cheong, K.J.; Kim, Y.I. \& Shin, S.C. (2010). Therapeutic effects of Baicalein on atopic dermatitis-like skin lesions of $\mathrm{NC} / \mathrm{Nga}$ mice induced by dermatophagoides pteronyssinus. International Immunopharmacology, Vol.10, No.9, (September 2010), pp. 1142-1148. 